\title{
Lipopolysaccharide Signals Activation of Tumor Necrosis Factor Biosynthesis Through the Ras/Raf-1/MEK/MAPK Pathway
}

\author{
Thomas D. Geppert,* Charles E. Whitehurst, ${ }^{\dagger}$ \\ Patricia Thompson, ${ }^{\neq}$and Bruce Beutler** \\ *The Department of Internal Medicine, University of Texas \\ Southwestern Medical Center at Dallas, Dallas, Texas, U.S.A. \\ ${ }^{+}$The Harold C. Simmons Arthritis Research Center, Dallas, \\ Texas, U.S.A. \\ ${ }^{\ddagger}$ The Howard Hughes Medical Institute, Dallas, Texas, U.S.A.
}

\begin{abstract}
Background: Lipopolysaccharide (LPS) is known to activate macrophages, causing the release of toxic cytokines that may provoke inflammation and shock. One of the most important and best studied of these cytokines is tumor necrosis factor (TNF). Details of the signaling pathway leading to TNF biosynthesis remain unclear. The pathway is branched in the sense that TNF gene transcription and TNF mRNA translation are both strongly stimulated by LPS. Recent evidence has indicated that MAP kinase homologs become phosphorylated in LPS-stimulated cells, suggesting their possible involvement in signal transduction. We sought to test this hypothesis.

Materials and Methods: Measurements of LPS-induced MEK and ERK2 activity were undertaken in LPS-sensitive and LPS-insensitive cells. Transfection studies, in which dominant inhibitors of ras and raf-1 were used to block signaling to the level of MAP kinase, were carried out in order to judge whether the TNF gene transcription and TNF mRNA translation are modulated through this pathway.
\end{abstract}

Results: In RAW 264.7 mouse macrophages, both ERK2 and MEK1 activity are induced by LPS treatment. In the same cell line, dominant negative inhibitors of ras and raf- 1 block LPS-induced activation of the TNF promoter, as well as derepression of the translational blockade normally imposed by the TNF 3 '-untranslated region. A constitutively active form of raf- 1 ( raf- $B X B$ ) was found to augment, but not replace, the LPS signal. In LPS-insensitive cells (RAW $264.7 \times$ NIH 3T3 fusion hybrid cells and primary macrophages derived from $\mathrm{C} 3 \mathrm{H} / \mathrm{HeJ}$ mice), ERK2 activity was found to be refractory to induction by LPS.

Conclusions: The ras/raf-1/MEK/MAPK pathway is chiefly responsible for transduction of the LPS signal to the level of the TNF gene and mRNA. raf and raf-1 lie upstream from (or actually represent) the physical branchpoints of the transcriptional and translation activation signals generated by LPS. The lesions that prevent LPS signaling in macrophages from $\mathrm{C} 3 \mathrm{H} / \mathrm{HeJ}$ mice, or in RAW $264.7 \times$ NIH 3T3 fusion hybrid cells, occupy a proximal position in the signaling pathway.

\section{INTRODUCTION}

Bacterial endotoxin (lipopolysaccharide; LPS) is believed to elicit most of its untoward effects by provoking cytokine synthesis in cells of reticuloendothelial origin, e.g., macrophages (1-3).

Address correspondence and reprint requests to: Bruce Beutler, Howard Hughes Medical Institute, U.T. Southwestern Medical Center, 5323 Harry Hines Blvd., Y5.210, Dallas, TX 75235-9050, U.S.A.
Tumor necrosis factor (TNF) is believed to be one of the most important of these cytokine mediators. Within $2 \mathrm{hr}$ following LPS stimulation, TNF is elaborated as one of the major secretory products of macrophages $(4,5)$. Passive immunization against TNF offers strong protection against the lethal effect of LPS (6), and direct administration of TNF causes shock and tissue injury (7).

For these reasons, the signal transduction pathway utilized by LPS, leading to the synthesis 
and release of TNF, assumes considerable importance. Moreover, responses of the TNF gene are an excellent endpoint for studies of LPS signaling in macrophages since the rate of TNF biosynthesis increases 1,000 -fold or more following stimulation by LPS (8). Previous work has established that LPS is concentrated through the formation of complexes with lipopolysaccharide binding protein (LBP) and then engages CDl4, a GPIlinked plasma membrane protein $(9,10)$. As CD 14 has no obvious means of generating signals within the cytoplasmic compartment, the initial triggering mechanism for LPS signaling remains obscure.

It is recognized that the LPS signal traverses a biological "bottleneck" in the sense that it is minimally dependent upon the product of a single gene, known as the Lps gene (11-13). It is widely assumed that this gene, defective in LPS-unresponsive $\mathrm{C} 3 \mathrm{H} / \mathrm{HeJ}$ and $\mathrm{C} 57 \mathrm{~B} 10 \mathrm{SnCr}$ mice, encodes an early component of the signal transduction apparatus. Once a signal has been initiated, the activation pathway bifurcates, ultimately yielding both transcriptional and translational activation of TNF biosynthesis (8). Transcriptional activation of TNF synthesis is minimally dependent upon NF- $\kappa \mathrm{B}$ translocation, insofar as deletion of the NF- $\kappa$ B motifs present in the TNF promoter/enhancer region is sufficient to abolish LPS responsiveness (14). Translational activation depends upon defeat of translational repression imposed by the UA-rich element present in the 3'-UTR of the mRNA encoding TNF and several other cytokines $(15,16)$.

TNF biosynthesis can be blocked by glucocorticoid agonists, which impede both transcriptional and translational activation pathways (8), by cAMP analogs or phosphodiesterase inhibitors, which selectively block the transcriptional response (17), and by pyridinyl imidazole derivatives, which selectively block the translational response (18). The molecular targets of each inhibitor remain to be determined; however, these data lend credence to the view that the signaling pathway bifurcates into transcriptional and translational components.

Certain aspects of the LPS signaling pathway appear to be unique to macrophages. Notably, when an immortalized mouse macrophage line (RAW 264.7) is fused with an immortalized fibroblast line (NIH 3T3) the resulting hybrid cells are endotoxin unresponsive (19). Presumably, essential component(s) of the LPS signal transduction pathway, like the TNF gene itself (19), are extinguished following fusion.
Although little is known about the biochemical signaling pathway responsible for transmitting signals generated by LPS to the nucleus, recent studies have suggested that it may be initiated by a tyrosine kinase (20-22). Thus, LPS induces tyrosine phosphorylation in monocytic cell lines and this response can be blocked by tyrosine kinase inhibitors $(20,21)$. Moreover, several functional consequences of LPS exposure can be inhibited by tyrosine kinase inhibitors $(20,22)$.

A number of tyrosine kinase initiated pathways activate a cascade of signaling molecules termed the mitogen-activated protein (MAP) kinase pathway $(23,24)$. Activation of the tyrosine kinase by receptor ligation leads to autophosphorylation of the kinase and association with an adaptor protein such as Grb2 through the SH2 domain of the adaptor protein (25). The adaptor protein is thought to bind to a guanine nucleotide exchange factor which in turn promotes the association of the proto-oncogene ras with GTP. GTP-bound ras binds to the proto-oncogene raf- 1 transporting it to the membrane where it is activated $(26-28)$. raf- 1 is a serine threonine kinase that phosphorylates and activates a family of protein kinases termed MAP kinase or extracellular signal-regulated kinases (MEKs) (29). MEKs phosphorylate MAP kinases on threonine and tyrosine residues increasing their catalytic activity 1,000-fold (30-32). MAP kinases include extracellular signal regulated kinase (ERK) 1, ERK2, ERK3, ERK4, p54 MAP kinases (JNK or SAPs), and p57 MAP kinases (33-37). One or more of these kinases are known to phosphorylate other protein kinases (e.g., Rsk, MAPKAP kinase 2), transcription factors (e.g., c-jun, myc, $\mathrm{p} 62^{\text {tcf }} / \mathrm{elk}$, tall, NF-IL6, and ATF-2) cytoskeletal proteins (microtubule-associated protein 2 , tau), and a number of enzymes (phospholipase $\mathrm{A}_{2}$ and tyrosine hydroxylase) (38). This pathway is thought to play an important role in cell growth and differentiation $(39,40)$. In addition, recent evidence has demonstrated that some members of this pathway are required for $\mathrm{T}$ cells to produce IL-2 following antigen recognition $(41,42)$.

Recent work has also suggested that LPS may trigger the activity of MAP kinases in monocytic and lymphocytic cell lines (21,43-45). Based on these findings, we considered that the MAP kinase pathway might transmit signals generated by LPS that are responsible for regulating TNF gene transcription and/or TNF mRNA translation. We therefore sought to investigate the role of the ras/raf-1/MEK/MAPK pathway in LPS-in- 
duced TNF production in macrophages. In order to do so, we studied the effect of LPS on the activity of the MAP kinase pathway in LPS-responsive and LPS-refractory cells. In addition, we sought to determine whether dominant inhibitory forms of ras and raf- 1 blocked LPS-induced TNF promoter activity, and finally, whether an activated mutant of raf-1 stimulated LPS-induced TNF promoter activity.

\section{MATERIALS AND METHODS}

\section{DNA Constructs}

raf- $B X B$ and raf-C4B have been described previously $(46,47)$. Both constructs were placed into a metallothionine-driven expression vector, pMEP (Invitrogen). pMEP contains the hygromycin resistance gene driven by the thymidine kinase promoter. A cDNA encoding a dominant inhibitory form of Ras $(17 \mathrm{~N}, 59 \mathrm{~T})$ was obtained from Dr. L. Feig (48). The cDNA was inserted into the pCEP4 vector for use in these studies. A construct containing the CAMP regulated enhancer element (CRE) driving CAT (49) was obtained from Dr. Marc Montminy (Salk Institute, La Jolla, CA, U.S.A.). Constructs in which a TNF promoter drives the expression of CAT, in which a CMV promoter drives the expression of CAT, and in which a CAT coding sequence is followed by the TNF 3'-UTR were described previously $(17,50)$.

\section{Reagents and Antibodies}

Phorbol myristate acetate (PMA; Sigma Chemical Co., St. Louis, MO, U.S.A.) was dissolved in ethanol and added to cells at a final concentration of $10 \mathrm{ng} / \mathrm{ml}$. E. coli LPS, from strain 0127:B8, was obtained from Difco. The LPS was dissolved at a concentration of $1.0 \mathrm{mg} / \mathrm{ml}$ in sterile saline and frozen at $-20^{\circ} \mathrm{C}$ until use. It was added to cultured cells at the concentrations and for the length of time indicated in each figure. 8-bromocAMP (Sigma) was added to RAW 264.7 cells cultures at a concentration of $100 \mu \mathrm{g} / \mathrm{ml}$ for a period of $24 \mathrm{hr}$ prior to harvest and CAT assay.

Rabbit polyclonal antisera raised to the ERK2 peptides A249 and 691, an antiserum raised to MEK1 specific peptides A2227, and preimmune antiserum were generously provided by Dr. Melanie Cobb (51). The production and biochemical characterization of recombinant histi- dine-tagged mutant $\mathrm{K} 7 \mathrm{l} \rightarrow \mathrm{R}$ human ERKl (rERK1) has been described previously (30).

\section{Stimulation of ERK2 or MEK1 activity by LPS or PMA}

Peritoneal macrophages were elicited from $\mathrm{C} 3 \mathrm{H} /$ $\mathrm{HeJ}$ or $\mathrm{C} 3 \mathrm{H} / \mathrm{HeN}$ mice by injecting the animals with $2.0 \mathrm{ml}$ of sterile Brewer's thioglycollate medium 4 days prior to harvest of the cells. Macrophages were obtained by peritoneal lavage with 10 cc of sterile heparinized Dulbecco's modified Eagle's medium (DMEM) supplemented with $10 \%$ fetal bovine serum (FBS). The cells were allowed to adhere to $10 \mathrm{~cm}$ plastic tissue culture dishes for a period of $2 \mathrm{hr}$. The dishes were then washed to remove nonadherent cells, leaving a purified population of macrophages.

RAW 264.7 cells [ATCC] and NIH 3T3 cells [ATCC] were fused to produce hybrids as previously described (19). The RAW 264.7 cells, and the fusion hybrids, were grown until nearly confluent in DMEM containing 10\% FBS. Sixteen hours before stimulation of RAW 264.7 cells, the fusion hybrids and peritoneal macrophages were cultured in medium containing $0.5 \%$ fetal calf serum (FCS) to minimize basal ERK2 activity. LPS or PMA were added to the cultures as indicated.

\section{ERK2 and MEK1 Immune Complex Kinase Assay}

Cells were lysed at $4^{\circ} \mathrm{C}$ in RIPA-H buffer $(20 \mathrm{mM}$ Tris, pH 8.0, $1.0 \%$ NP40, 0.5\% deoxycholic acid, $0.1 \%$ SDS, $150 \mathrm{mM} \mathrm{NaCl}, 3 \mathrm{mM} \mathrm{MgCl} 2,6 \mathrm{mM}$ EGTA, $1 \mathrm{mM}$ DTT, $20 \mathrm{mM}$ p-nitrophenyl phosphate, $50 \mathrm{mM} \mathrm{NaF}, 50 \mu \mathrm{M} \mathrm{Na}_{3} \mathrm{VO}_{4}, 10 \mu \mathrm{g} / \mathrm{ml}$ of aprotinin, $1 \mathrm{mM}$ leupeptin, $1 \mathrm{mM}$ PMSF, and 5 $\mathrm{mM}$ benzamidine). The lysates were clarified by centrifugation $(15,000 \mathrm{X} \mathrm{g} ; 10 \mathrm{~min})$, split into two equal fractions, and incubated with either 5 $\mu \mathrm{l}$ of A249, $5 \mu \mathrm{l}$ of preimmune sera, $10 \mu \mathrm{l} \mathrm{A2227}$ (anti-MEK1 antiserum), or $10 \mu \mathrm{l}$ of control serum. Immune complexes were precipitated using SPA agarose. The immune complexes were washed once with RIPA-H buffer, once with 0.5 $\mathrm{M} \mathrm{LiCl}, 100 \mathrm{mM}$ Tris, $\mathrm{pH} 7.5$, and once with 50 $\mathrm{mM}$ Tris, $\mathrm{pH} 7.6,100 \mathrm{mM} \mathrm{NaCl}$. The resulting pellets were incubated at $30^{\circ} \mathrm{C}$ for $30 \mathrm{~min}$ in a reaction buffer containing $20 \mathrm{mM}$ HEPES, pH 7.5, $10 \mathrm{mM} \mathrm{MgCl} 2,1 \mathrm{mM}$ DTT, $1 \mathrm{mM}$ benzamidine, $1 \mathrm{mM}$ EGTA, $50 \mu \mathrm{M}\left[\tau_{-}{ }^{32} \mathrm{P}\right]$ ATP $(5,200$ $\mathrm{cpm} / \mathrm{pmol}$ ), and substrate. Myelin basic protein (MBP) was used as a substrate for the ERK2 
assay whereas $\mathrm{K} 7 \mathrm{l} \rightarrow \mathrm{R}$ rERKl $(25 \mu \mathrm{g} / \mathrm{ml})$ was used as a substrate for MEKl. The reactions were stopped by boiling in gel loading buffer and examined by $12 \%$ SDS-PAGE, Coomassie staining, and autoradiography. The amount of phosphate incorporated into MBP or $\mathrm{K} 71 \rightarrow \mathrm{R}$ rERK1 bands was determined by excising the bands and subjecting them to liquid scintillation. Data are expressed as picomoles of phosphate incorporated per milligram of protein in the cellular lysate.

\section{Transfection and CAT assay}

Cells were cotransfected with CAT reporter plasmids and with plasmids encoding dominant inhibitors of ras, raf-1, or empty control vectors using the method of Chen and Okayama (52). Forty-eight hours after transfection, the cells were harvested for CAT assay as previously described $(53,54)$. CAT activity was quantitated, when specified, by phosphorimager analysis.

\section{RESULTS}

\section{LPS Stimulates the Activity of MEK 1 and ERK2 in RAW 264.7 Cells, but Not in RAW 264.7 X 3T3 Hybrid Cells}

In initial studies we examined the effect of LPS on the activity of the MAP kinase signaling pathway in the highly LPS-responsive RAW 264.7 cell line. This was assessed by measuring the effect of LPS on MEK1 and ERK2 activity in RAW 264.7 cells using immune complex kinase assays. LPS stimulated MEK1 and ERK2 activity in RAW 264.7 cells (Fig. 1) but in an atypical fashion. MEKI and ERK2 activity were detectable 30 min after LPS was added to the cultures and activity peaked $60 \mathrm{~min}$ after stimulation. The response was independent of LPS-induced protein synthesis, however, as indicated by the fact that cycloheximide did not diminish kinase activation (data not shown). ERK2 induction was detected when LPS was added to the culture at concentrations as low as $10 \mathrm{ng} / \mathrm{ml}$. Higher concentrations of LPS stimulated higher levels of ERK2 induction, and a maximal response was observed with the addition of LPS at a concentration of $1 \mu \mathrm{g} / \mathrm{ml}$ (Fig. 2).

By contrast, ERK2 activity was not induced in RAW $264.7 \times 3 \mathrm{~T} 3$ hybrid cells which, as previously noted, fail to support LPS-induced TNF promoter responses (19) (Fig. 3). The hybrid cells were, however, responsive to PMA induction; higher levels of ERK2 activity were induced by

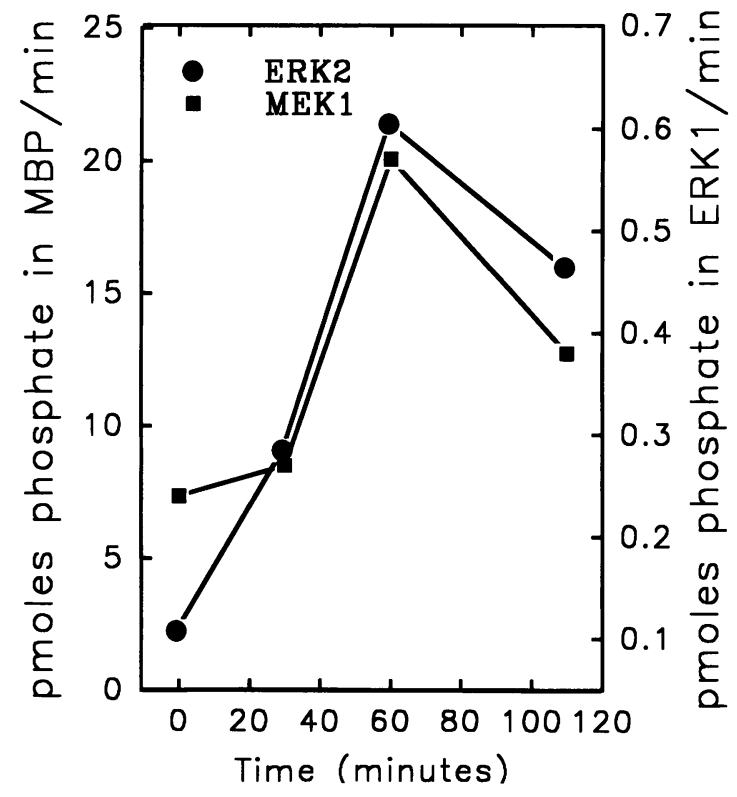

FIG. 1. LPS stimulates MEK1 and ERK2 activity in Raw 264.7 cell

RAW 264.7 cells were cultured in medium containing $0.5 \%$ FCS overnight to minimize basal ERK2 and MEKl activity. LPS was added to the cultures at a concentration of $100 \mathrm{ng} / \mathrm{ml}$, and the cells were lysed in RIPA buffer at varying times thereafter. MEK1 and ERK2 activity was assessed using immune complex kinase assays as described in Materials and Methods. Each point represents a single determination.

PMA in hybrid cells than in RAW 264.7 cells. Moreover, the concentration of ERK present in the hybrid cells was comparable to that in RAW 264.7 cells as determined by immunoblotting (data not shown).

\section{LPS Does Not Activate ERK2 in $\mathrm{C} 3 \mathrm{H} / \mathrm{HeJ}$ Macrophages}

In a related set of experiments, primary thioglycollate-elicited macrophages from $\mathrm{C} 3 \mathrm{H} / \mathrm{HeN}$ and from $\mathrm{C} 3 \mathrm{H} / \mathrm{HeJ}$ mice were stimulated with LPS in vitro. While LPS did not stimulate ERK2 activity in peritoneal macrophages isolated from $\mathrm{C} 3 \mathrm{H} /$ HeJ mice, it did stimulate ERK2 activity in peritoneal macrophages from $\mathrm{C} 3 \mathrm{H} / \mathrm{HeN}$ mice. ERK2 could be activated by PMA in both cell types (Fig. 4). The concentration of ERK2 in PMA-stimulated $\mathrm{C} 3 \mathrm{H} / \mathrm{HeJ}$ macrophages was comparable to that observed in $\mathrm{C} 3 \mathrm{H} / \mathrm{HeN}$ macrophages. 


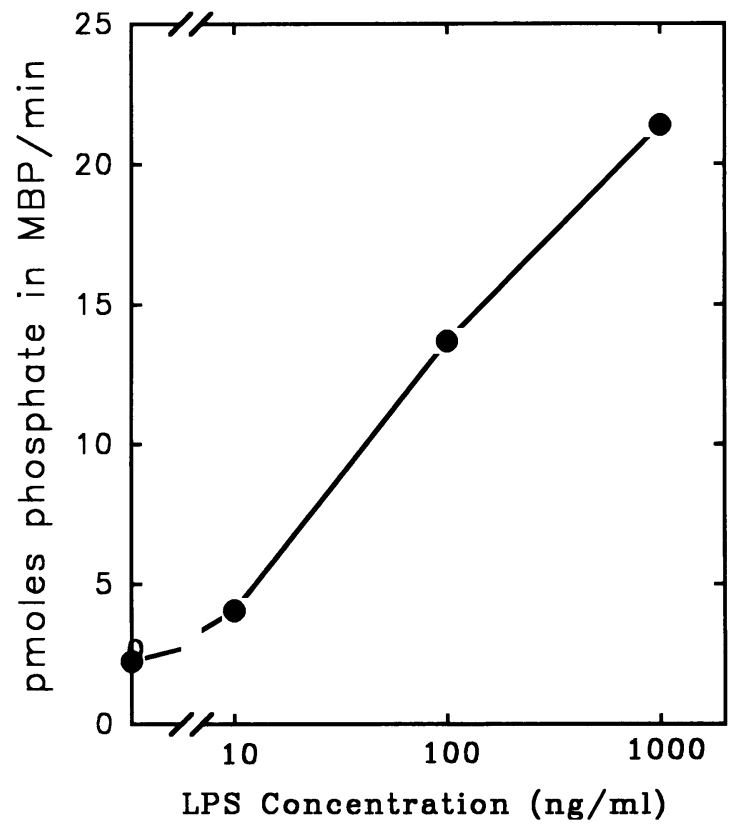

FIG. 2. ERK2 activity in RAW 264.7 cells stimulated with varying concentrations of LPS

RAW 264.7 cells were exposed to varying concentrations of LPS or left unstimulated after overnight culture in medium containing $0.5 \%$ FCS. Immune complex kinase assay was performed as described in Materials and Methods. Each point represents a single determination.

\section{Dominant Inhibitors of ras and raf- 1 Effectively Block LPS-Induced Responses of the TNF Promoter}

Since MEK1 and ERK2 activity can, in other systems, be activated through activation of ras

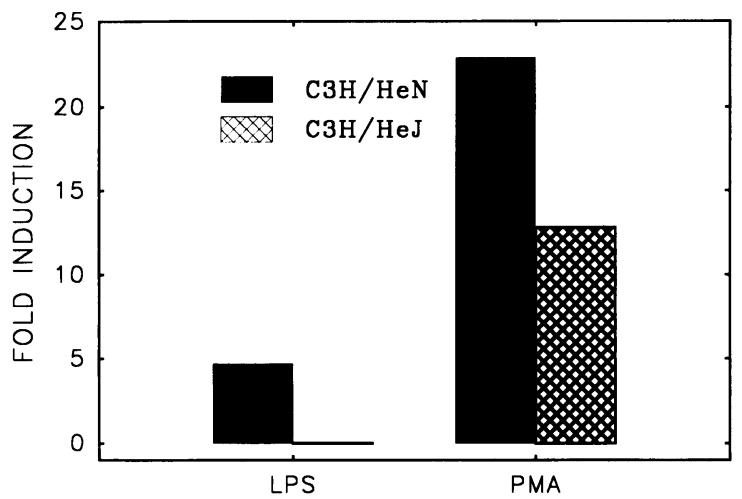

FIG. 4. LPS does not stimulate ERK2 activity in peritoneal macrophages isolated from C3H/HeJ mice

Peritoneal macrophages isolated from $\mathrm{C} 3 \mathrm{H} / \mathrm{HeJ}$ or $\mathrm{C} 3 \mathrm{H} / \mathrm{HeN}$ mice were cultured overnight in plastic petri dishes in medium containing $0.5 \%$ FCS. LPS ( $250 \mathrm{ng} / \mathrm{ml})$ or PMA $(10 \mathrm{ng} / \mathrm{ml})$ was added to each culture, and the cells were lysed in RIPA buffer $1 \mathrm{hr}$ later. ERK2 activity was assessed using an immune complex kinase assay as described in Materials and Methods. The results are expressed as a ratio of the ERK2 activity present in LPS- or PMA-stimulated cells to the ERK2 activity present in unstimulated controls (i.e., fold induction).

and raf- 1 , we attempted to determine whether LPS signaling entails activation of these proteins. Mutant forms of both raf and ras, which inhibit the activity of the endogenous signaling molecules when expressed in cells, have been identified previously. These mutant molecules are termed dominant inhibitory ras or raf-1. Cotrans-

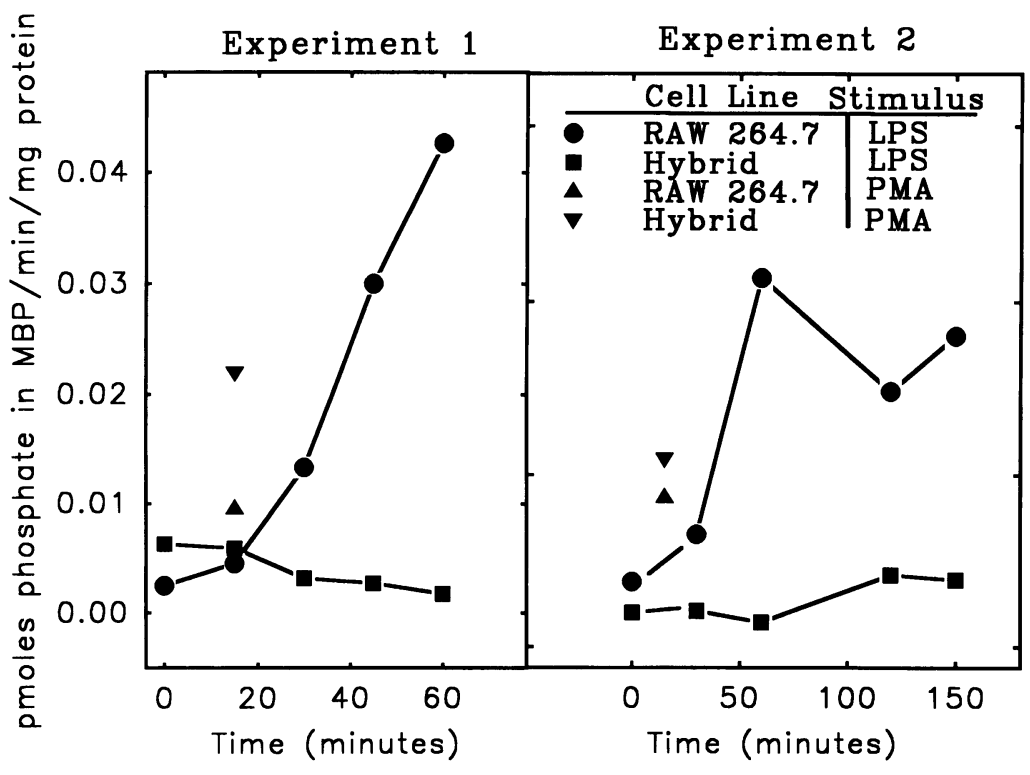

FIG. 3. LPS does not stimulate ERK2 activity in a hybrid cell line

0.03

LPS was added at a concentration of $1 \mu \mathrm{g} / \mathrm{ml}$ to RAW 264.7 cells or fusion hybrid cells that had been cultured overnight in medium containing $0.5 \%$ FCS. At various times after adding LPS the cells were lysed in RIPA buffer and ERK2 activity was assessed using an immune complex kinase assay as described in Materials and Methods. To assay the response to PMA, cells were stimulated with this agent and harvested 15 min afterward. Two representative experiments are shown. 


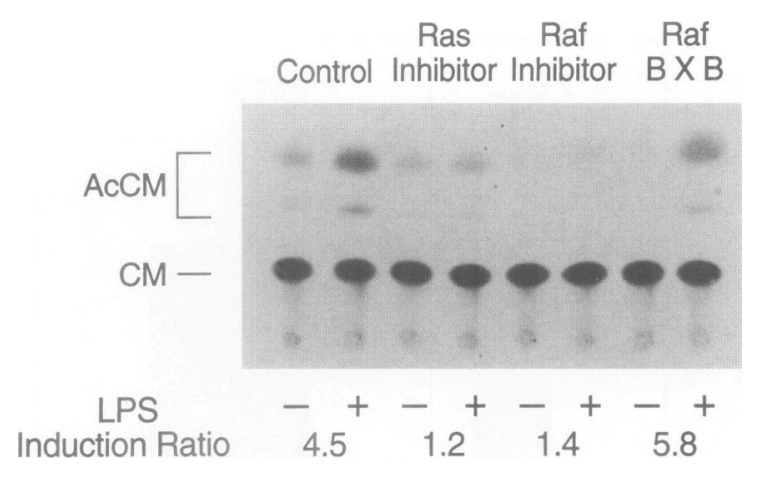

FIG. 5. Effects of dominant inhibitors of ras and raf-1, and the active raf-BXB protein, on responses of the TNF promoter to LPS

RAW 264.7 cells were cotransfected with expression constructs encoding each of these proteins, or with an empty vector (control), and with a TNF promoter-CAT construct. Cells were stimulated with LPS at a concentration of $1 \mu \mathrm{g} / \mathrm{ml} 24 \mathrm{hr}$ after transfection and harvested and lysed for determination of CAT activity $48 \mathrm{hr}$ after transfection, as described in Materials and Methods. The ratio of CAT activity in stimulated versus unstimulated cells (LPS induction ratio) was calculated on the basis of phosphorimager analysis. CM, chloramphenicol; AcCM, acetylated forms of chloramphenicol.

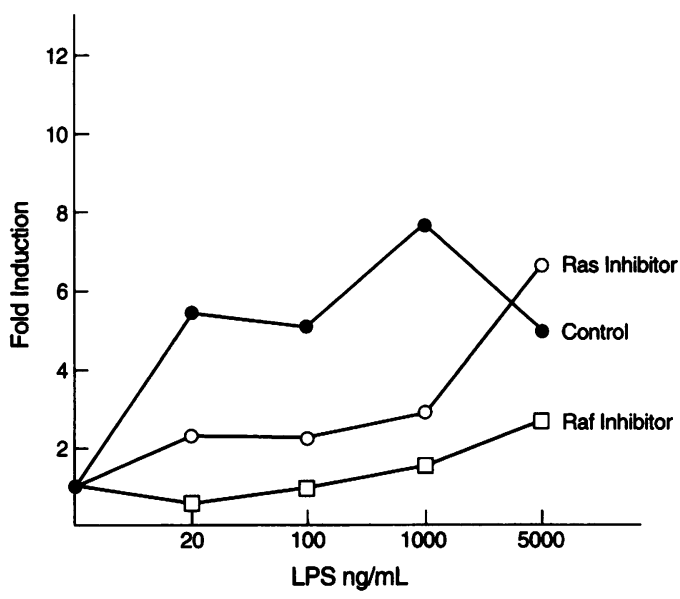

A fection of a dominant inhibitory ras expression construct into RAW 264.7 cells markedly diminished LPS-induced TNF promoter activation over a range of concentrations beneath $1 \mu \mathrm{g} / \mathrm{ml}$ (Figs. 5 and 6A); at higher concentrations of LPS, cotransfection with the dominant negative ras construct did not block promoter activation. A dominant negative raf-1 inhibitor also consistently decreased the response to low concentrations of LPS (Figs. 5 and 6A). As with the ras inhibitor, high concentrations of LPS were capable of stimulating the TNF promoter even in the presence of co-transfected raf- 1 inhibitor. A deletion mutant of raf- 1 lacking the regulatory domain (raf-BXB) has been found to be constitutively active in some cell types $(46,48)$. This construct augmented the response of the reporter gene to all concentrations of LPS (Figs. 5and 6B).

In some experiments (Fig. 7), a cAMP-responsive promoter was cotransfected with each of the two dominant-negative expression constructs and was still found responsive to induction by 8-bromo-cAMP. Moreover, the activity of the LPS-unresponsive CMV promoter was not influenced by cotransfection with either the ras or raf- 1 inhibitors. Hence, the effect of the inhibitors was a specific one and appeared to impact

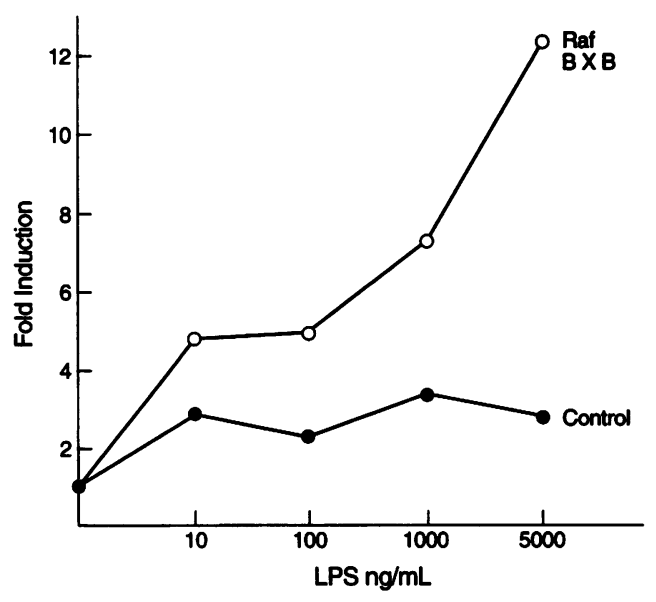

B

FIG. 6. TNF promoter responses to different LPS concentrations in the presence of dominant inhibitors of ras and raf-1 or in the presence of raf-BXB

Cells were cotransfected with ras, raf-1 (A), or raf-BXB (B) expression constructs or empty vector (control) and with a TNF promoter-CAT construct as described in Materials and Methods. Twenty-four hours later, they were induced with LPS at the concentration indicated. Forty-eight hours post-transfection, the cells were lysed and CAT activity was measured. The relative activity of CAT in stimulated cells, with respect to the activity in control cells, is presented. A separate control was used for each series of cotransfections. 


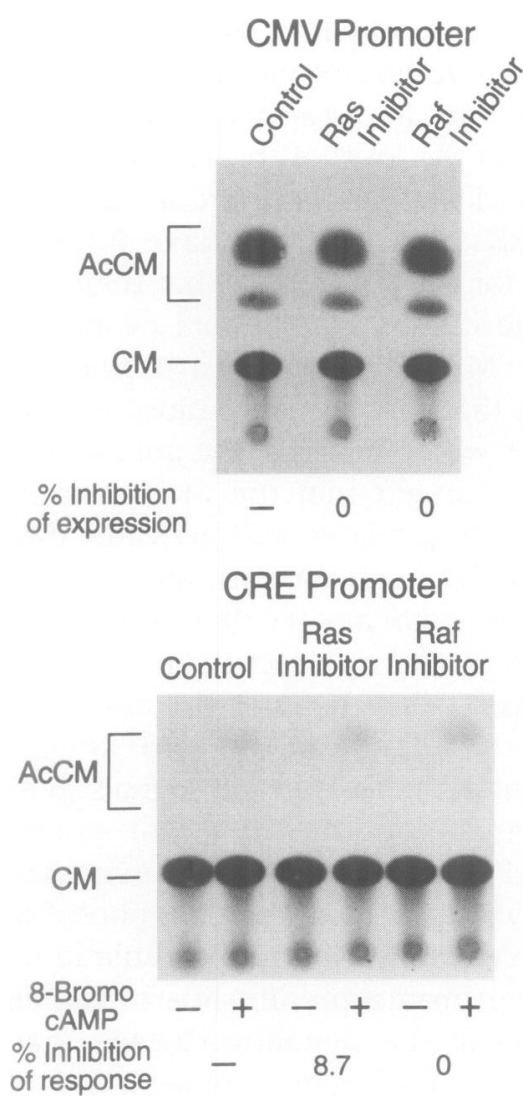

FIG. 7. CMV promoter activity and CRE promoter activity are not influenced by cotransfection with dominant inhibitors of ras or raf-1

The CMV promoter, which is expressed constitutively in RAW 264.7 cells, and a CRE-containing promoter, which is expressed in RAW 264.7 cells in response to dibutyryl cAMP stimulation, were used to drive CAT mRNA transcription and cotransfected into RAW 264.7 cells together with empty vector (control) or constructs encoding dominant ras or raf- 1 inhibitors. CAT activity was assayed $48 \mathrm{hr}$ after transfection and $24 \mathrm{hr}$ after stimulation with 8bromo-cAMP (in the case of the CRE promoter-CAT system). Little or no inhibitory effect resulted from inhibitor cotransfection.

upon signaling rather than upon the expression of CAT activity per se.

Finally, a reporter construct designed to detect signals that affect translational efficiency was cotransfected with ras and raf- 1 inhibitors. In this reporter a CMV promoter was used to drive expression of a CAT-coding sequence to which the TNF 3'-UTR was appended. As previously noted, the reporter was observed to be LPS-responsive in RAW 264.7 cells. Cotransfection of ras and raf-1 inhibitor constructs abolished the LPS response of this construct, just as it abolished the

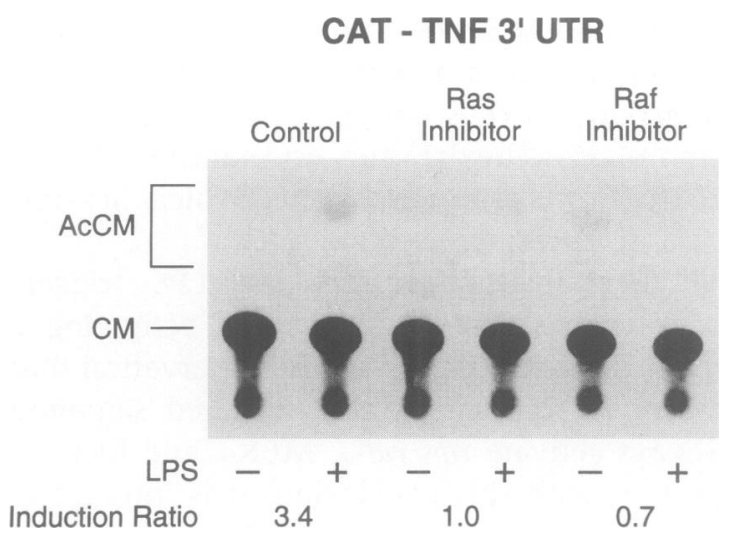

FIG. 8. Release of translational blockade imposed by the TNF 3'-UTR is prevented by dominant inhibitors of ras and raf-1.

RAW 264.7 cells were cotransfected with a reporter construct in which a CMV promoter was used to drive transcription of a CAT mRNA in which the TNF 3'-UTR was appended, together with empty vector (control) or vectors encoding dominant inhibitors of ras or raf-1. Cultures were induced with LPS at a concentration $1 \mu \mathrm{g} / \mathrm{ml} 24 \mathrm{hr}$ after transfection, and cells were harvested for CAT assay $48 \mathrm{hr}$ after transfection. Quantitation of CAT activity, and calculation of the induction ratio, was performed using a phosphorimager. CM, chloramphenicol; AcCM, acetylated forms of chloramphenicol.

response of the TNF promoter CAT construct (Fig. 8).

\section{DISCUSSION}

We have examined the role of the MAP kinase pathway in LPS-induced TNF gene activation. The data demonstrate that LPS induces MEK1 and ERK2 activity in cell types that produce TNF when exposed to LPS, but not in two cell types that have lost the ability to produce TNF when stimulated by LPS. Thus, the activity of the MAP kinase pathway correlates with LPS-induced TNF production. In addition, dominant inhibitory forms of raf-1 and ras block LPS-induced TNF promoter activation. The LPS responsive 3'-UTR, which confers translational blockade in resting cells $(15,16)$, also fails to react to LPS in the presence of dominant inhibitory ras and raf-1 proteins. We conclude that at least two components of the MAP kinase pathway, ras and raf-1, are required for LPS-induced TNF production.

The finding that LPS does not stimulate ERK2 activity in macrophages from $\mathrm{C} 3 \mathrm{H} / \mathrm{HeJ}$ mice is consistent with previous work demon- 
strating that LPS does not stimulate tyrosine phosphorylation or a crude increase in MAP kinase activity in cells obtained from mice of this strain $(44,55)$. The data suggest that the defect in $\mathrm{C} 3 \mathrm{H} / \mathrm{HeJ}$ mice is an early one, which lies upstream of ERK2.

It has been suggested that LPS triggers changes in cellular physiology by activating a tyrosine kinase $(20-22,44)$. The observation that a variety of tyrosine kinase-initiated signaling pathways activate ras, raf-1, MEKs, and ERKs is consistent with this conclusion. It is interesting to note, however, that in most of the previously described signal transduction pathways, the relevant upstream stimulus induces ERK activity within minutes. For example, ERK and MEK1 activity peak $5 \mathrm{~min}$ after stimulation via the T cell receptor in T cells (56). A similar rate of response is observed when NGF is applied to cells that express the NGF receptor (57). The delayed response witnessed in macrophages exposed to LPS may suggest tardive activation of a certain upstream tyrosine kinase. Notably, however, ERK2 activity is stimulated in the presence of protein synthesis inhibitors (data not shown), indicating that stimulation of a pre-existing pathway, rather than the assembly of a new pathway through protein synthesis, occurs in the course of activation.

It is interesting to note that the inhibitory effect of dominant negative forms of raf- 1 and ras on the transcriptional activity of the TNF promoter induced by LPS varies depending upon the concentration of LPS that is used. Thus, whereas the stimulatory effect of a low concentration of LPS is completely blocked, higher concentrations of LPS do effect a TNF promoter response. There are at least two plausible explanations for this finding. It is clear that increasing concentrations of LPS lead to increased activity of the pathway. It is possible that, if signals of sufficient intensity are generated, dominant inhibitory raf- 1 and ras proteins cannot fully block the pathway, thus preventing enhanced TNF promoter activity. Alternatively, LPS may activate several parallel pathways that regulate TNF gene transcription. At high concentrations of LPS, the activity of these alternate pathways may be sufficient to stimulate the TNF promoter despite effective blockade of the MAP kinase pathway. Taken together, the data indicate that the MAP kinase pathway plays an important role in LPS signaling and that this role is particularly important when LPS concentrations are low.

Although we used MEK1 and ERK2 activity as a measure of the activity of the MAP kinase pathway we do not intend to imply that MEK1 or ERK2 are necessarily involved in transducing signals to the level of the TNF gene or mRNA. It is now clear that there are a number of MEKs and ERKs, that each may have different requirements for activation, and that their activity may regulate different functional events. For example, the MAP kinase pathway is known to deliver signals that increase the transcriptional activity of AP- 1 which consists of c-jun and c-fos (58). It is now thought that the MAP kinase homolog that phosphorylates and activates c-jun is JNK $(59,60)$. ERKs, in contrast, are thought to phosphorylate c-jun at sites that inhibit the ability of c-jun to promote transcription $(61,62)$. A variety of signals that activate ERKs also activate JNK. While the identity of the MAP kinase homolog that functions to transmit signals generated by LPS remains unknown, recent studies by Han et al. (45) suggest that the mammalian homolog of the yeast $\mathrm{Hog}$ gene becomes phosphorylated in 70Z/3 cells following LPS stimulation. This protein then may represent one of the distal components of the signaling cascade that leads to enhanced TNF gene transcription and TNF mRNA translation.

It is interesting to note that expression of the free catalytic domain of raf, which is constitutively active in a variety of cell types, is not sufficient to induce TNF promoter activity. There are several potential explanations for this finding. First, raf- $B X B$ may be inactive in macrophages unless stimulated by LPS. We have observed a similar phenomenon in T cells, in which raf- $B X B$ is not constitutively active, but is regulated by engagement of the $T$ cell receptor for antigen (T. D. Geppert, unpublished data). Alternatively, the MAP kinase pathway may be necessary but not sufficient for TNF promoter activity. Thus, there may be a parallel pathway that does not involve raf- $B X B$ that is required for TNF promoter activity. Whatever the explanation, the finding that raf- $B X B$ activity promotes LPS-induced TNF promoter activity supports the hypothesis that raf-1 activity is required for LPSinduced TNF production.

Activated raf- 1 has recently been shown to phosphorylate $\mathrm{I} \kappa \mathrm{B}$ in a manner that allows NF- $\kappa B$ to separate from $I \kappa B$ and proceed to the nucleus (63). raf-1 is also known to phosphorylate MEK1. As such, it may represent at least one of the physical branchpoints in the LPS signaling pathway, which, as noted above, resolves into both transcriptional and translational compo- 
nents. Viewed from this perspective, it seems likely that specific MAP kinase homolog(s) lie on the pathway leading to activation of the translational response.

\section{ACKNOWLEDGMENTS}

This work was supported in part by an NIH Cancer Immunology Training Grant, the Texas Department Ladies Auxiliary Veterans of Foreign Wars, The Council for Tobacco Research (3634 R1), and an NIH grant (5-PO-1DK42582).

\section{REFERENCES}

1. Michalek SM, Moore RN, McGhee JR, Rosenstreich DL, Mergenhagen SE. (1980) The primary role of lymphoreticular cells in the mediation of host responses to bacterial endotoxin. J. Inf. Dis. 141:55-63.

2. Galanos C, Freudenberg MA. (1993) Mechanisms of endotoxin shock and endotoxin hypersensitivity. Immunobiology 187: 346356.

3. Freudenberg MA, Keppler D, Galanos C. (1986) Requirement for lipopolysaccharideresponsive macrophages in galactosamineinduced sensitization to endotoxin. Inf. Immun. 51: 891-895.

4. Beutler B, Mahoney J, Le Trang N, Pekala P, Cerami A. (1985) Purification of cachectin, a lipoprotein lipase-suppressing hormone secreted by endotoxin-induced RAW 264.7 cells. J. Exp. Med. 161: 984-995.

5. Beutler B, Greenwald D, Hulmes JD, et al. (1985) Identity of tumour necrosis factor and the macrophage-secreted factor cachectin. Nature 316: 552-554.

6. Beutler B, Milsark IW, Cerami A. (1985) Passive immunization against cachectin/tumor necrosis factor (TNF) protects mice from the lethal effect of endotoxin. Science 229: 869-871.

7. Tracey KJ, Beutler B, Lowry SF, et al. (1986) Shock and tissue injury induced by recombinant human cachectin. Science 234: 470474.

8. Beutler B, Krochin N, Milsark IW, Luedke C, Cerami A. (1986) Control of cachectin (tumor necrosis factor) synthesis: mechanisms of endotoxin resistance. Science 232: 977980.

9. Wright SD, Ramos RA, Tobias PS, Ulevitch
RJ, Mathison JC. (1990) CD 14, a receptor for complexes of lipopolysaccharide (LPS) and LPS binding protein. Science 249: 1431-1433.

10. Hailman E, Lichenstein HS, Wurfel MM, et al. (1994) Lipopolysaccharide (LPS)-binding protein accelerates the binding of LPS to CD14. J. Exp. Med. 179: 269-277.

11. Watson J, Kelly K, Largen M, Taylor BA. (1978) The genetic mapping of a defective LPS response gene in $\mathrm{C} 3 \mathrm{H} / \mathrm{HeJ}$ mice. $\mathrm{J}$. Immunol. 120: 422-424.

12. Watson J, Riblet R, Taylor BA. (1977) The response of recombinant inbred strains of mice to bacterial lipopolysaccharides. $\mathrm{J}$. Immunol. 118: 2088-2093.

13. Vogel SN. (1992) The Lps gene: Insights into the genetic and molecular basis of LPS responsiveness and macrophage differentiation. In: Beutler B (ed). Tumor Necrosis Factors: The Molecules and Their Emerging Role in Medicine. Raven Press, New York, pp. 485513.

14. Shakhov AN, Collart MA, Vassalli P, Nedospasov SA, Jongeneel CV. (1990) $\kappa B$-type enhancers are involved in lipopolysaccharide-mediated transcriptional activation of the tumor necrosis factor $\alpha$ gene in primary macrophages. J. Exp. Med. 171: 35-47.

15. Han J, Brown T, Beutler B. (1990) Endotoxin-responsive sequences control cachectin/ TNF biosynthesis at the translational level. $J$. Exp. Med. 171: 465-475.

16. Kruys V, Marinx O, Shaw G, Deschamps J, Huez G. (1989) Translational blockade imposed by cytokine-derived UA-rich sequences. Science 245: 852-855.

17. Han J, Thompson P, Beutler B. (1990) Dexamethasone and pentoxifylline inhibit endotoxin-induced cachectin/TNF synthesis at separate points in the signalling pathway. $J$. Exp. Med. 172: 391-394.

18. Young $P$, McDonnell $P$, Dunnington $D$, Hand A, Laydon J, Lee J. (1993) Pyridinyl imidazoles inhibit IL-1 and TNF production at the protein level. Agents Actions 39 Suppl. C: C67-C69.

19. Kruys V, Thompson P, Beutler B. (1993) Extinction of the tumor necrosis factor locus, and of genes encoding the lipopolysaccharide signaling pathway. J. Exp. Med. 177: 1383-1390.

20. Geng Y, Zhang B, Lotz M. (1993) Protein tyrosine kinase activation is required for lipopolysaccharide induction of cytokines in 
human blood monocytes. J. Immunol. 151: 6692-6700.

21. Weinstein SL, Gold MR, DeFranco AL. (1991) Bacterial lipopolysaccharide stimulates protein tyrosine phosphorylation in macrophages. Proc. Natl. Acad. Sci. U.S.A. 88: 4148-4152.

22. Novogrodsky A, Vanichkin A, Patya M, Gazit A, Osherov N, Levitzki A. (1994) Prevention of lipopolysaccharide-induced lethal toxicity by tyrosine kinase inhibitors. Science 264: 1319-1319.

23. Cobb MH, Robbins DJ, Boulton TG. (1991) ERKs, extracellular signal-regulated MAP2 kinases. Curr. Opin. Cell Biol. 3: 1025-1032.

24. Pazin MJ, Williams LT. (1992) Triggering signaling cascades by receptor tyrosine kinases. Trends Biochem. Sci. 17: 374-378.

25. White MF, Kahn CR. (1994) The insulin signaling system. J. Biol. Chem. 269: 1-4.

26. Warne PH, Viciana PR, Downward J. (1993) Direct interaction of Ras and the amino-terminal region of Raf-1 in vitro. Nature 364: 352-355.

27. Vojtek AB, Hollenberg SM, Cooper JA. (1993) Mammalian Ras interacts directly with the serine/threonine kinase Raf. Cell 74: 205-214.

28. Moodie SA, Willumsen BM, Weber MJ, Wolfman A. (1993) Complexes of Ras-GTP with Raf-1 and Mitogen-Activated Protein Kinase Kinase. Science 260: 1658-1661.

29. Kyriakis JM, App H, Zhang XF, et al. (1992) Raf- 1 activates MAP kinase-kinase. Nature 358: 417-421.

30. Robbins DJ, Zhen E, Owaki H, et al. (1993) Regulation and properties of extracellular signal-regulated protein kinases 1 and 2 in vitro. J. Biol. Chem. 268: 5097-5106.

31. Crews CM, Alessandrini A, Erikson RL. (1992) The primary structure of MEK, a protein kinase that phosphorylates the ERK gene product. Science 258: 478-480.

32. Seger R, Ahn NG, Posada J, et al. (1992) Purification and characterization of mitogen-activated protein kinase activator(s) from epidermal growth factor-stimulated A431 cells. J. Biol. Chem. 267: 14373-14381.

33. Boulton TG, Cobb MH. (1991) Identification of multiple extracellular signal-regulated kinases (ERKs) with antipeptide antibodies. Cell Reg. 2: 357-371.

34. Boulton TG, Yancopoulos GD, Gregory JS, et al. (1990) An insulin-stimulated protein ki- nase similar to yeast kinases involved in cell cycle control. Science 249: 64-67.

35. Boulton TG, Nye SH, Robbins DJ, et al. (1991) ERKs: A family of protein-serine/ threonine kinases that are activated and tyrosine phosphorylated in response to insulin and NGF. Cell 65: 663-675.

36. Lee H, Ghose-Dastidar J, Winawer S, Friedman E. (1993) Signal transduction through extracellular signal-regulated kinase-like pp57 blocked in differentiated cells having low protein kinase Cbeta activity. J. Biol. Chem. 268: 5255-5263.

37. Kyriakis JM, Avruch J. (1990) pp54 Microtubule-associated protein 2 kinase. A novel serine/threonine protein kinase regulated by phosphorylation and stimulated by poly-Llysine. J. Biol. Chem. 265: 17355-17363.

38. Cobb MH, Helper JE, Cheng M, Robbins D. (1994) The mitogen-activated protein kinases, ERK1 and ERK2. Sem. Cancer Biol. 5: $1-8$.

39. MacNicol AM, Muslin AJ, Williams LT. (1993) Raf-1 kinase is essential for early Xenopus development and mediates the induction of mesoderm by FGF. Cell 73: 571-583.

40. Sontag E, Fedorov S, Kamibayashi C, Robbins D, Cobb M, Mumby M. (1993) The interaction of SV40 small tumor antigen with protein phosphatase $2 \mathrm{~A}$ stimulates the map kinase pathway and induces cell proliferation. Cell 75: 887-897.

41. Owaki H, Varma R, Gillis B, et al. (1993) Raf-1 is required for T cell IL2 production. EMBO J. 12: 4367-4373.

42. Rayter SI, Woodrow M, Lucas SC, Cantrell DA, Downward J. (1992) p2 $1^{\text {ras }}$ mediates control of $I L-2$ gene promoter function in $\mathrm{T}$ cell activation. EMBO J. 11: 4549-4556.

43. Han J, Lee J-D, Tobias PS, Ulevitch RJ. (1993) Endotoxin induces rapid protein tyrosine phosphorylation in $70 \mathrm{Z} / 3$ cells expressing CD14. J. Biol. Chem. 268: 2500925014.

44. Dong Z, Qi X, Fidler IJ. (1993) Tyrosine phosphorylation of mitogen-activated protein kinases is necessary for activation of murine macrophages by natural and synthetic bacterial products. J. Exp. Med. 177: 1071-1071.

45. Han J, Lee J-D, Bibbs L, Ulevitch RJ. (1994) A MAP kinase targeted by endotoxin and hyperosmolarity in mammalian cells. Science, in press.

46. Bruder JT, Heidecker G, Rapp UR. (1992) 
Serum-, TPA-, and Ras-induced expression from Ap-1/Ets-driven promoters requires Raf-1 kinase. Genes. Dev. 6: 545-556.

47. Heidecker G, Huleihel M, Cleveland JL, et al. (1990) Mutational activation of c-raf-1 and definition of the minimal transforming sequence. Mol. Cell. Biol. 10: 2503-2512.

48. Feig, L. A. and G. M. Cooper. (1988) Inhibition of NIH 3T3 cell proliferation by a mutant ras protein with preferential affinity for GDP. Mol. Cell. Biol. 8: 3235.

49. Yamamoto KK, Gonzalez GA, Biggs WH III, Montminy MR. (1988) Phosphorylation-induced binding and transcriptional efficacy of nuclear factor CREB. Nature 334: 494-498.

50. Han J, Huez G, Beutler B. (1991) Interactive effects of the TNF promoter and 3'-untranslated regions. J. Immunol. 146: 1843-1848.

51. Boulton TG, Cobb MH. (1991) Identification of multiple extracellular signal-regulated kinases (ERKs) with antipeptide antibodies. Cell Reg. 2: 357-371.

52. Chen C, Okayama H. (1987) High-efficiency transformation of mammalian cells by plasmid DNA. Mol. Cell. Biol. 7: 2745-2752.

53. Gorman CM, Moffat LF, Howard BH. (1982) Recombinant genomes which express chloramphenicol acetyltransferase in mammalian cells. Mol. Cell. Biol. 2: 1044-1051.

54. Beutler B, Brown T. (1991) A CAT reporter construct allows ultrasensitive estimation of TNF synthesis, and suggests that the TNF gene has been silenced in non-macrophage cell lines. J. Clin. Invest. 87: 1336-1344.

55. Manthey CL, Brandes ME, Perera PY, Vogel SN. (1992) Taxol increases steady-state levels of lipopolysaccharide-inducible genes and protein-tyrosine phosphorylation in murine macrophages. J. Immunol. 149: 24592465.

56. Whitehurst CE, Boulton TG, Cobb MH, Gep- pert TD. (1992) Extracellular signal regulated kinases in T cells: Anti-CD3 and 4Bphorbol 12-myristate 13-acetate-induced phosphorylation and activation. J. Immunol. 148: $3230-3237$.

57. Robbins DJ, Cobb MH. (1992) ERK2 autophosphorylation on a subset of peptides phophorylated in intact cells by insulin and NGF: Analysis by peptide mapping. Mol. Biol. Cell 3: 299-308.

58. Karin M, Smeal T. (1992) Control of transcription factors by signal transduction pathways: the beginning of the end. Trends Biochem. Sci. 17: 418-422.

59. D'rijard B, Hibi M, Wu I-H, et al. (1994) JNK1: A protein kinase stimulated by UV light and Ha-Ras that binds and phosphorylates the c-Jun activation domain. Cell 76: 1025-1037.

60. Hibi M, Lin A, Smeal T, Minden A, Karin M. (1993) Identification of an oncoprotein- and UV-responsive protein kinase that binds and potentiates the c-Jun activation domain. Genes Dev. 7: 2135-2148.

61. Chou SY, Baichwal V, Ferrell JE. (1992) Inhibition of c-jun DNA binding by mitogen activated protein kinase. Mol. Biol. Cell 3: $1117-1130$.

62. Alvarez E, Northwood IC, Gonzalez FA, et al. (1991) Pro-Leu-Ser/Thr-Pro is a consensus primary sequence for substrate protein phosphorylation. Characterization of the phosphorylation of c-myc and c-jun proteins by an epidermal growth factor receptor threonine 669 protein kinase. J. Biol. Chem. 266: 15277-15285.

63. Li S, Sedivy JM. (1993) Raf-1 protein kinase activates the NF- $\kappa \mathrm{B}$ transcription factor by dissociating the cytoplasmic NF- $\kappa \mathrm{B}-\mathrm{I} \kappa \mathrm{B}$ complex. Proc. Natl. Acad. Sci. U.S.A. 90: 9247-9251. 